\title{
SISTEM PAKAR DIAGNOSIS PENYAKIT DEMAM BERDARAH MENGGUNAKAN METODE CASE BASED REASONING BERBASIS WEB
}

\author{
Haryo Bimo Wijayanto ${ }^{1}$, Joseph Dedy Irawan $^{2}$, Ahmad Faisol ${ }^{3}$ \\ Program Studi Teknik Informatika S1, Fakultas Teknologi Industri \\ Institut Teknologi Nasional Malang, Jalan Raya Karanglo km 2 Malang, Indonesia \\ haryobimowijayanto@gmail.com
}

\begin{abstract}
ABSTRAK
Penyebab utama semakin meningkatnya tingkat meninggal dunia akibat terlambat dalam penanganan penyakit demam berdarah. Penyakit demam berdarah menyerang manusia dengan cara menyebarkan virus dari nyamuk. Jenis penyakit demam berdarah yaitu demam dengue dan demam berdarah dengue. Untuk mengetahui bahwa pasien terkena Demam Berdarah dibutuhkan pemeriksaan laboratorium yang dilakukan oleh dokter. Karena dengan melihat suhu badan dan trombosit dapat diketahui apakah pasien sedang terkena demam berdarah. Gejala fisik yang dialami oleh pasien terkadang berbeda karena tiap seseorang memiliki daya tubuh yang berbeda.

Sistem pakar dibuat untuk menangani pencegahan dalam penanganan penyakit demam berdarah. Metode yang digunakan dalam penelitian ini adalah case based reasoning . Dengan metode ini dapat membandingkan antara kasus lama dan kasus baru. Dalam perhitungan ini menggunakan perbandingan dengan menggunakan rumus similarity.

Hasil dari metode case based reasoning diperoleh perbandingan antara perhitungan manual dan menggunakan sistem tingkat akurasi yang dihasilkan adalah $100 \%$.
\end{abstract}

Kata Kunci : Demam Berdarah, Sistem Pakar, Case Based Reasoning

\section{PENDAHULUAN}

\subsection{Rumusan Masalah}

Demam berdarah adalah salah satu penyakit yang dapat menyerang siapa saja. Demam berdarah sendiri terbagi beberapa jenis yaitu Demam Dengue dan Demam Berdarah Dengue. Untuk mengetahui bahwa pasien terkena Demam Berdarah dibutuhkan pemeriksaan laboratorium yang dilakukan oleh dokter. Karena dengan melihat suhu badan dan trombosit dapat diketahui apakah pasien sedang terkena demam berdarah. Gejala fisik yang dialami oleh pasien terkadang berbeda karena tiap seseorang memiliki daya tubuh yang berbeda.

Kekurangan dari sistem diagnosis saat ini masih kurang nya analisa terhadap penyakit yang dialami oleh pasien. Karena perhitungan yang tepat membutuhkan data yang banyak. Karena metode yang digunakan berbasis kasus. Dengan pemeriksaan laboratorium dokter langsung dapat diagnosis riwayat apa yang sedang dialami oleh pasien.

Maka dari itu untuk membuat sistem pakar saya menggunakan metode case based reasoning. Alasan saya menggunakan metode case based reasoning karena disini saya perlu membandingkan kasus lama dan kasus baru. Dimana setiap pasien memiliki hasil laboratorium yang berbeda. Dengan sistem pakar ini diharapkan dapat membantu dokter dalam melakukan diagnosis penyakit demam berdarah. Untuk platform yang digunakan adalah berbasis web.

\subsection{Rumusan Masalah}

Berdasarkan latar belakang yang telah dikemukakan di atas, maka dapat dibuat sebuah rumusan masalah yaitu "Bagaimana mengembangkan sistem pakar untuk diagnosis penyakit demam berdarah menggunakan metode Case Based Reasoning berbasis web”.

\subsection{Batasan Masalah}

Agar permasalahan yang dimaksud tidak meluas, lebih terarah dan mudah dipahami maka diperlukan suatu batasan masalah dalam penelitian ini. Adapun batasan permasalahan pada penelitian ini, yaitu :

1. Data yang digunakan pada pengembangan sistem ini merupakan dari UPTD Puskesmas Gondanglegi

2. Metode yang digunakan adalah Cased Based Reasoning

3. Platform yang digunakan adalah berbasis website

4. Sistem dibuat untuk dokter

5. Bahasa pemrogaman yang digunakan adalah PHP Native, CSS, dan menggunakan database $M y S Q L$

\section{TINJAUAN PUSTAKA}

Pada tahun 2017 eka wahyudi dkk membahas tentang diagnosis penyakit jantung menggunakan metode case based reasoning. Menurut data rekam medis RSUP Dr. Sardjito Yogyakarta jumlah penyakit jantung dari tahun ketahun terus meningkat. Untuk dapat mendiagnosis penyakit jantung pasien yang menderita dapat diketahui melalui gejala yang dialami oleh pasien. Penanganan dapat dilakukan oleh ahli jantung, karena terbatasnya tenaga ahli yaitu dokter spesialis jantung dapat menghambat 
penanganan pasien. Sehingga dibutuhkan nya suatu alat untuk diagnosis penyakit jantung. Rekam medik untuk diagnosis penyakit dapat digunakan untuk acuan jenis penyakit jantung apa yang sedang diderita oleh pasien. (Wahyudi, 2017)

Pada tahun yang sama sri wahyuni nasution dkk membahas tentang sistem pakar tentang diagnosis anoreksia nervosa dengan menggunakan metode case based reasoning. Pada masa remaja banyak perubahan yang terjadi. Selain perubahan fisik karena bertambahnya masa otot juga bertambahnya jaringan lemak dalam tubuh serta terjadi perubahan hormonal. Pola makan remaja dapat mempengaruhi pertumbuhan dan akan berdampak pada penyakit kronis dikemudian hari. Pemenuhan gizi yang seimbang merupakan kebutuhan fisik setiap orang dan jika terpenuhi maka akan berpengaruh terhadap produktivitas seseorang. Minimya pengetahuan dan kepedulian terhadap keseimbangan gizi pada tubuh merupakan penyebab munculnya gangguan Anoreksia Nervosa ini. (Nasution, 2017)

Pada tahun sebelum nya dito putro utomo dan teman nya membahas tentang sistem pakar yang digunakan untuk diagnosis kerusakan pada toner menggunakan metode case based reasoning. Teknik printing (printer) sudah berkembang secara pesat pada saat ini, sudah banyak jenis dan tipe printer yang beredar dipasaran, printer sangat membantu manusia didalam pengerjaan laporan ataupun segala hal yang berhubungan dengan pencetakan. Teknik printing (printer) sudah berkembang secara pesat pada saat ini, sudah banyak jenis dan tipe printer yang beredar dipasaran, printer sangat membantu manusia didalam pengerjaan laporan ataupun segala hal yang berhubungan dengan pencetakan. Permasalahan toner ini bisa saja terjadi dikarenakan ketidakpandaian kita didalam penggunaan ataupun jangka waktu ( masa waktu ) toner tersebut. (Utomo 2016)

Pada tahun 2014 Faza Akmal dan teman nya membahas tentang sistem pakar yang digunakan untuk mendiagnosis penyakit lambung, faza menggunakan metode case based reasoning untuk sistem pakar nya. Penyakit lambung dapat disebabkan oleh pola makan yang tidak sesuai, beban pikiran dan juga infeksi yang disebabkan oleh bakteri. Untuk meminimalkan terjadi nya penyakit lambung maka diperlukan penerapan teknologi secara maksimal. Salah satu teknologi nya adalah menggunakan sistem pakar. (Akmal, 2014)

\subsection{Website}

Sebuah situs web (sering pula disingkat menjadi situs saja, website atau site) adalah sebutan bagi sekelompok halaman web ( web page), yang umumnya merupakan bagian dari suatu nama domain ( domain name ) atau subdomain di World Wide Web

$(W W W)$ di Internet. Sebuah web page adalah dokumen yang ditulis dalam format HTML (Hyper Text Markup Language), yang hampir selalu bisa diakses melalui HTTP, yaitu protokol yang menyampaikan informasi dari server website untuk ditampilkan kepada para pemakai melalui web browser baik yang bersifat statis maupun dinamis yang membentuk satu rangkaian bangunan yang saling terkait dimana masing-masing dihubungkan dengan jaringan-jaringan halaman (hyperlink) (Harminingtyas, 2014)

\subsection{PHP (Hypertext Preprocessor)}

PHP atau kependekan dari Hypertext Preprocessor adalah salah satu bahasa pemrograman open source yang sangat cocok atau dikhususkan untuk pengembangan web dan dapat ditanamkan pada sebuah skripsi HTML. Bahasa PHP dapat dikatakan menggambarkan beberapa bahasa pemrograman seperti C, Java, dan Perl serta mudah untuk dipelajari.

Adapun pengertian lain PHP adalah akronim dari Hypertext Preprocessor, yaitu suatu bahasa pemrogramannberbasiskan kode - kode (script) yang digunakan untuk mengolah suatu data dan mengirimkannya kembali ke web browser menjadi kode HTML".(Firman, 2016)

\subsection{HTML (Hyper Text Markup Language)}

HTML (Hyper Text Markup Language) sebenarnya bukan sebuah Bahasa pemrograman, karena HTML adalah bahasa mark up. HTML digunakan untuk mark up (penanda) terhadap suatu dokumen teks. Simbol mark up yang digunakan oleh HTML ditandai dengan tanda lebih kecil $(<)$ dan tanda lebih besar (>). Kedua tanda ini disebut tag. Tag yang digunakan sebagai tanda penutup diberi karakter garis miring $(</ . .>)$..(Binarso, 2012)

\subsection{CSS (Cascading Style Sheet)}

CSS (Cascading Style Sheet) adalah stylesheet language yang digunakan untuk mendeskripsikan penyajian dari dokumen yang dibuat dalam mark up language. CSS merupakan sebuah dokumen yang berguna untuk melakukan pengaturan pada komponen halaman web, inti dari dokumen ini adalah memformat halaman web standar menjadi bentuk web yang memiliki kualitas yang lebih indah dan menarik.(Binarso, 2012)

\subsection{Bootstrap}

Bootstrap adalah front-end framework yang bagus dan luar biasa yang mengedapankan tampilan untuk mobiledevice (Handphone, smartphone dll.) guna mempercepat dan mempermudah pengembangan website. Bootstrap menyediakan HTML, CSS dan Javascript siap pakai dan mudah untuk dikembangkan. Bootstrap merupakan framework untuk membangun desain web secara responsif. Artinya, tampilan web yang dibuat oleh bootstrapakan menyesuaikan ukuran layar dari browser yang kita gunakan baik di desktop, tablet ataupun mobile device. Fitur ini bisa diaktifkan 
ataupun dinonaktifkan sesuai dengan keinginan kita sendiri.Sehingga, kita bisa membuat web untuk tampilan desktop saja dan apabila dirender oleh mobile browser maka tampilan dari web yang kita buat tidak bisa beradaptasi sesuai layar. Dengan bootstrap kita juga bisa membangun web dinamis ataupun statis.(Effendy, 2016)

\section{6. $\mathrm{MySQL}$}

MySQL merupakan database yang paling digemari dikalangan Programmer Web, dengan alasan bahwa program ini merupakan database yang sangat kuat dan cukup stabil untuk digunakan sebagai media penyimpanan data. Sebagai sebuah database Server yang mampu untuk memanajemen dengan baik, MySQL terhitung merupakan database yang paling digemari dan paling banyak digunakan dibanding database lainnya. Selain MySQL masih terdapat beberapa jenis database server yang juga memiliki kemampuan yang juga tidak bisa dianggap sepele, database itu adalah Oracle, PostgreSQL dan lain-lain. Salah satu database yang digunakan adalah MySQL(Adriantantri,2012)

\subsection{Sistem Pakar}

Sistem pakar (Expert System) adalah cabang dari kecerdasan buatan (AI) dan juga ilmu yang muncul pada pengembangan IT hari ini. Menurut Giarratano dan Riley adalah sistem pakar adalah sistem komputer yang bisa menyamai atau meniru kemampuan seorang ahli. Sistem ini bekerja untuk mengadopsi pengetahuan manusia dalam komputer yang menggabungkan basis pengetahuan (knowledge base) dengan sistem inferensi untuk menggantikan fungsi pakardalam sebuah memecahkan masalah.(Nasution, dkk.2017)

\subsection{Metode Cosine Similarity}

Cosine similarity adalah ukuran kesamaan yang lebih umum digunakan dalam information retrieval dan merupakan ukuran sudut antara dokumen (titik (ax,bx)) dan (titik (ay,by))(Imbar,dkk.2014). Dengan jarak antara 0 sampai 1 , jika hasil mendekati 1 maka jarak perhitungan berdekatan begitu juga sebaliknya.

$$
\cos C=\frac{a_{x} b_{x}+a_{y} b_{y}}{\sqrt{a_{x}{ }^{2}+a_{y}{ }^{2}} x \sqrt{b_{x}{ }^{2}+b_{y}{ }^{2}}}
$$

Gambar 1 Perhitungan Cosine Similarity

\subsection{Metode Case Based Reasoning}

Secara singkat Case-Based Reasoning (CBR) didefinisikan sebagai sebuah metodologi untuk penyelesaian masalah dengan memanfaatkan pengalaman sebelumnya. Case-Based reasoning (CBR) merupakan sebuah paradigma utama dalam penalaran otomatis (automated reasoning) dan mesin pembelajaran (machine learning). Didalam CBR, seseorang yang melakukan penalaran dapat menyelesaikan masalah baru dengan memperhatikan kesamaannya dengan satu atau beberapa penyelesaian dari permasalahan sebelumnya.

Case-Based reasoning (CBR) merupakan sebuah paradigma utama dalam penalaran otomatis (automated reasoning) dan mesin pembelajaran (machine learning). Didalam CBR, seseorang yang melakukan penalaran dapat menyelesaikan masalah baru dengan memperhatikan kesamaannya dengan satu atau beberapa penyelesaian dari permasalahan sebelumnya. Metode Case-Based Reasoning (CBR) merupakan penalaran berbasis kasus menyelesaikan masalah baru dengan mengadaptasi solusi yang digunakan untuk menyelesaikan masalah yang lama (Utomo.2016)

Ada 4 tahapan proses yang ada di dalam sistem penalaran komputer berbasis kasus, yaitu:

1. Retrieve, mendapatkan kasus-kasus yang mirip.

2. Reuse, menggunakan kembali kasus-kasus yang ada dan dicoba untuk menyelesaikan suatu masalah sekarang.

3. Revise, merubah dan mengadopsi solusi yang ditawarkan jika perlu.

4. Retain, memakai solusi baru sebagai bagian dari kasus baru, kemudian kasus baru diupdate kedalam basis kasus.(Nasution,dkk.2017)

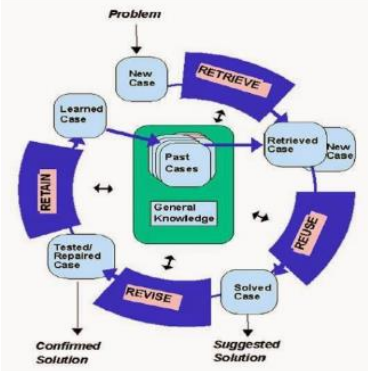

Gambar 2 Tahap Case Based Resoning

\section{METODE PENELITIAN}

\subsection{Tabel Kasus Pasien}

Dalam perancangan data dijelaskan data-data yang terdapat dalam sistem sesuai dengan fungsinya sebagai data input ataupun data output. Berikut ini adalah data kriteria yang digunakan dalam penelitian ini: 
Tabel 1 Data Kasus

\begin{tabular}{|c|c|c|c|c|c|c|c|c|c|c|c|c|c|}
\hline z & 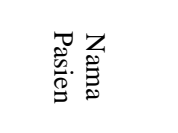 & 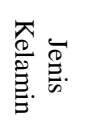 & S & 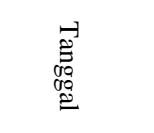 & $\stackrel{\mathscr{E}}{\Xi}$ & $\begin{array}{l}Z \\
\stackrel{Z}{:}\end{array}$ & $\vec{g}$ & 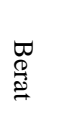 & 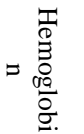 & $\begin{array}{l}5 \\
0 \\
\underbrace{}_{\hat{0}} \\
= \\
=\end{array}$ & 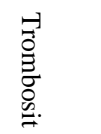 & 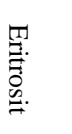 & 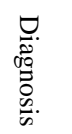 \\
\hline 1 & $\begin{array}{l}\text { Wahyu Suryo } \\
\text { Utomo }\end{array}$ & $\begin{array}{c}\text { Laki- } \\
\text { Laki }\end{array}$ & 32 & 17 JULI 2019 & 38 & 88 & $130 / 90$ & 84 & 14,7 & 3000 & 106.000 & 4,46 & DD \\
\hline 2 & Jihan Makaila & $\begin{array}{l}\text { Peremp } \\
\text { uan }\end{array}$ & 5 & $\begin{array}{l}\text { 12 MARET } \\
2019\end{array}$ & 39 & 90 & $120 / 80$ & 13.6 & 12,2 & 2800 & 121000 & 4,2 & DD \\
\hline 3 & Mutamimah & $\begin{array}{l}\text { Peremp } \\
\text { uan }\end{array}$ & 24 & 25 JUNI 2019 & 38 & 80 & $90 / 60$ & 48 & 13,8 & 3000 & 145000 & 4,6 & DD \\
\hline 4 & $\begin{array}{l}\text { Naila Al } \\
\text { Zahra }\end{array}$ & $\begin{array}{l}\text { Peremp } \\
\text { uan }\end{array}$ & 2 & $\begin{array}{l}\text { 4 JANUARI } \\
2019\end{array}$ & 38 & 101 & $110 / 90$ & 10 & 12 & 4000 & 150000 & 4,2 & DD \\
\hline 5 & M.Zainal & $\begin{array}{l}\text { Laki- } \\
\text { Laki }\end{array}$ & 24 & 24 JUNI 2019 & 39 & 80 & $100 / 70$ & 45 & 13,7 & 1500 & 147000 & 5,07 & DD \\
\hline 6 & Ella Dwi & $\begin{array}{l}\text { Peremp } \\
\text { uan }\end{array}$ & 16 & $\begin{array}{l}4 \text { JANUARI } \\
2019\end{array}$ & 41 & 88 & $100 / 70$ & 50 & 13,3 & 4600 & 93000 & 4,43 & DHF \\
\hline 7 & $\begin{array}{l}\text { Nikmatul } \\
\text { Hasanah }\end{array}$ & $\begin{array}{l}\text { Peremp } \\
\text { uan }\end{array}$ & 35 & $\begin{array}{l}\text { 9 MARET } \\
2019\end{array}$ & 40 & 85 & $120 / 80$ & 39 & 13,5 & 3600 & 90000 & 4,84 & DHF \\
\hline 8 & Moh Sodik & $\begin{array}{l}\text { Laki- } \\
\text { Laki }\end{array}$ & 58 & $\begin{array}{l}20 \\
\text { DESEMBER } \\
2019\end{array}$ & 39 & 80 & $110 / 80$ & 45 & 11,7 & 3700 & 79000 & 3,64 & DHF \\
\hline 9 & $\begin{array}{l}\text { Egania } \\
\text { Wulandari }\end{array}$ & $\begin{array}{l}\text { Peremp } \\
\text { uan }\end{array}$ & 47 & $\begin{array}{l}\text { 13 MARET } \\
2019\end{array}$ & 38 & 80 & $110 / 70$ & 63 & 16,5 & 4100 & 50000 & 5,43 & DHF \\
\hline 10 & Arik Farida & $\begin{array}{l}\text { Peremp } \\
\text { uan }\end{array}$ & 32 & $\begin{array}{l}19 \\
\text { FEBRUARI } \\
2019\end{array}$ & 38 & 86 & $110 / 70$ & 80 & 13,6 & 3400 & 66000 & 4,29 & DHF \\
\hline 11 & Tursiani & $\begin{array}{l}\text { Peremp } \\
\text { uan }\end{array}$ & 49 & $\begin{array}{l}3 \\
\text { NOPEMBER } \\
2019\end{array}$ & 38 & 108 & $130 / 80$ & 60 & 14,8 & 4300 & 120000 & 5,5 & DD \\
\hline 12 & Hanina & $\begin{array}{l}\text { Peremp } \\
\text { uan }\end{array}$ & 5 & $\begin{array}{l}\text { 29 JANUARI } \\
2019\end{array}$ & 39 & 90 & $120 / 80$ & 13 & 11,7 & 5500 & 64000 & 5,4 & DHF \\
\hline 13 & $\begin{array}{l}\text { Nurul } \\
\text { Mutrainah }\end{array}$ & $\begin{array}{l}\text { Peremp } \\
\text { uan }\end{array}$ & 35 & $\begin{array}{l}\text { 16 JANUARI } \\
2019\end{array}$ & 40 & 115 & $120 / 80$ & 70 & 13,8 & 5700 & 96000 & 4,37 & DHF \\
\hline 14 & Alwi & $\begin{array}{l}\text { Peremp } \\
\text { uan }\end{array}$ & 39 & $\begin{array}{l}\text { 15 JANUARI } \\
2019\end{array}$ & 38 & 90 & $90 / 80$ & 57 & 15,1 & 9000 & 54000 & 4,7 & DHF \\
\hline
\end{tabular}

\subsection{Data Flow Diagram Level 0}

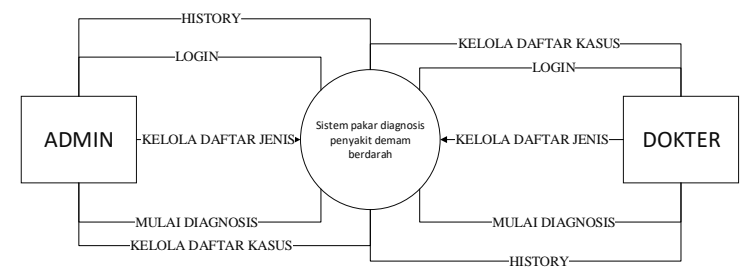

Gambar 3. DFD level 0

Pada gambar 3 adalah DFD Level 0 dari penyakit demam berdarah. Pada DFD Level 0 terdapat 2 user yaitu admin dan dokter. Pada proses ini admin dan dokter memiliki akses yang sama terhadap fitur yang disediakan. Admin dan dokter dapat mengakses login, daftar jenis, daftar kasus, mulai diagnosis, dan history

\subsection{Use Case Diagram}

Perancangan sistem menguraikan bagaimana interaksi yang di lakukan oleh admin dan pasien. Maka dari itu diperlukan use case agar mengetahui fungsi yang dilakukan oleh aktor. Fungsi yang dimaksud adalah aktifitas yang dilakukan pada masing-masing aktor memiliki batasan akses ke halaman yang di sediakan oleh sistem

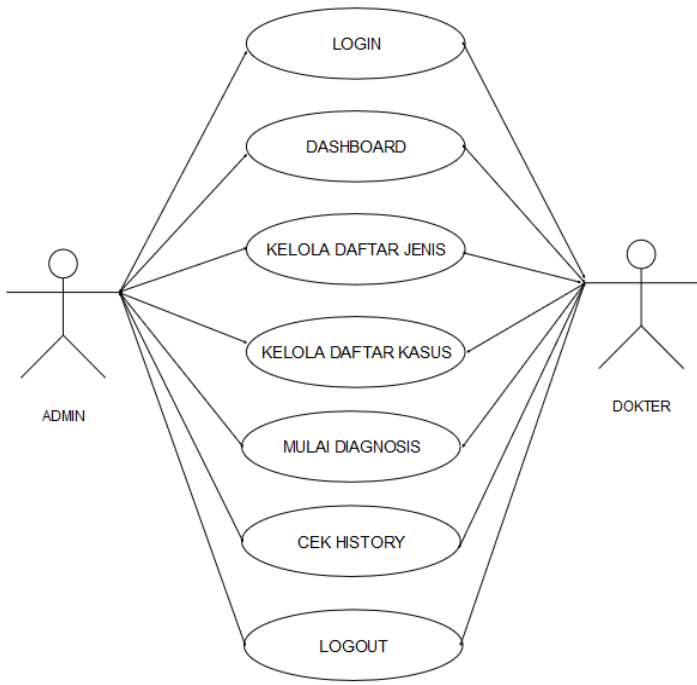

Gambar 4. Use Case Diagram

Use Case Diagram pada gambar 4 ada beberapa fitur didalam website sistem pakar. Admin dapat mengakses login admin, daftar user, daftar fase, daftar gejala, daftar kasus, data pasien, registrasi pasien, login pasien, halaman diagnosis, hasil diagnosis. Admin memiliki akses kesemua fitur yang 
ada dalam website. Untuk pasien memiliki akses registrasi pasien, login pasien, halaman diagnosis dan hasil diagnosis.

\section{HASIL DAN PEMBAHASAN \\ 4.1. Halaman Login}

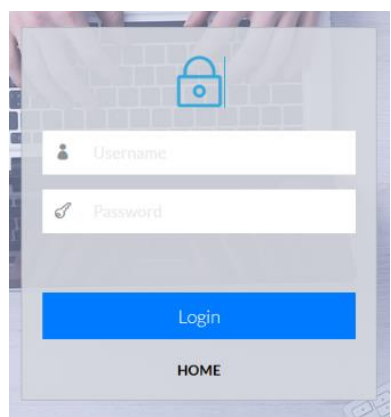

Gambar 7. Halaman login

Halaman login digunakan untuk login ke halaman admin. Pada tambah user terdapat username, password dan nama lengkap. Setelah admin klik simpan akan muncul pada daftar user

\subsection{Halaman Daftar User}

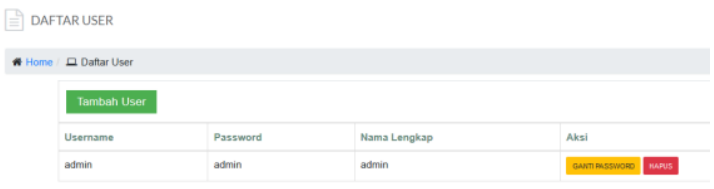

Gambar 8. Halaman Daftar User

Halaman daftar user digunakan untuk menampilkan daftar user(admin) yang telah ditambahkan oleh admin. Pada tampilan ini terdapat username dan password dimana kedua tersebut dapat digunakan untuk mengakses login ke halaman admin. Admin juga dapat merubah password atau menghapus data.

\subsection{Halaman Daftar Jenis}

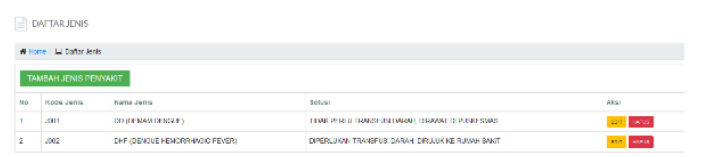

Gambar 9. Halaman daftar jenis

Halaman daftar fase digunakan untuk menampilkan data fase yang telah ditambahkan oleh admin. Pada halaman ini admin dapat mengedit kode fase, nama fase, dan definisi.

\subsection{Halaman Daftar Kasus}

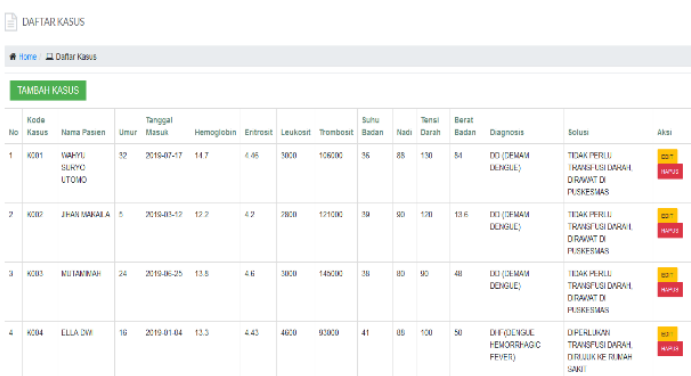

Gambar 10. Halaman daftar kasus

Halaman daftar gejala digunakan untuk menampilkan data gejala yang telah ditambahkan oleh admin. Pada halaman ini admin dapat mengedit kode gejala, dan nama gejala

\subsection{Pengujian Perhitungan Manual}

Pada pengujian ini dibutuhkan perhitungan manual pada pengujian ini dibutuhkan perbandingan antara perhitungan manual dan menggunakan sistem.

Perhitungan menggunakan similarity

Rumus :

$$
\cos C=\frac{a_{x} b_{x}+a_{y} b_{y}}{\sqrt{a_{x}^{2}+a_{y}^{2}} x \sqrt{b_{x}^{2}+b_{y}^{2}}}
$$

1. Perhitungan Similarity

Kasus K001

$13.7 \times 14.7+5.07 \times 4.46+1500 \times 3000+147000 \times 106000+39 \times 36$ $\sqrt{13.7^{2}+5.07^{2}+1500^{2}+147000^{2}+39^{2}} x \sqrt{14.7^{2}+4.46^{2}+3000^{2}+106000^{2}+36}$

$=\frac{15586501706}{147008 \times 106042}$

$=0,999836364$

2. Perhitungan Similarity Kasus K005 $\cos C$ $13.7 \times 13.5+5.07 \times 4.84+1500 \times 3600+147000 \times 90000+39 \times 40$ $\sqrt{13.7^{2}+5.07^{2}+1500^{2}+147000^{2}+39^{2}} \times \sqrt{13.5^{2}+4.84^{2}+3600^{2}+90000^{2}+40}$

$$
\begin{aligned}
& =\frac{13235401769}{147007.6536 \times 90071.98125} \\
& =0.999556776
\end{aligned}
$$

Hasil perhitungan sesuai dengan kasus tingkat kemiripan sesuai dengan Kasus K001

Tabel 2 Kasus 1

\begin{tabular}{|l|l|l|l|}
\hline \multicolumn{1}{|c|}{ Kasus } & \multicolumn{2}{c|}{ Kasus Lama } & \multicolumn{1}{c|}{$\begin{array}{c}\text { Kasus } \\
\text { Baru }\end{array}$} \\
\hline Kode Kasus & K001 & K005 & \\
\hline Umur & 32 & 35 & 24 \\
\hline Hemoglobin & 14.7 & 13.5 & 13.7 \\
\hline Eritrosit & 4.46 & 4.84 & 5.07 \\
\hline Leukosit & 3000 & 3600 & 1500 \\
\hline Trombosit & 106000 & 90000 & 147000 \\
\hline Suhu Badan & 36 & 40 & 39 \\
\hline Nadi & 88 & 85 & 80 \\
\hline Tensi Darah & 130 & 120 & 100 \\
\hline Berat Badan & 84 & 39 & 45 \\
\hline Diagnosis & DD (Demam & DHF(DENGUE & $\ldots \ldots \ldots \ldots$ \\
& Dengue) & HEMORRHAGIC & \\
\hline Solusi & & FEVER) & \\
\hline
\end{tabular}




\subsection{Pengujian Fungsional Black-Box}

Rencana pengujian yang akan dilakukan dengan menguji sistem dengan metode black-box

1. Pengujian dilakukan pada halaman login. login admin terdapat inputan berupa username dan password. Tampilan halaman login terdapat pada gambar 11

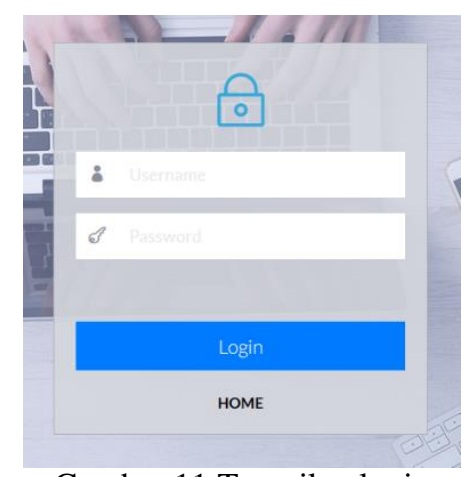

Gambar 11 Tampilan login

2. Pengujian login didapat hasil pada saat username dan password tidak diisi akan muncul pesan error seperti gambar 12

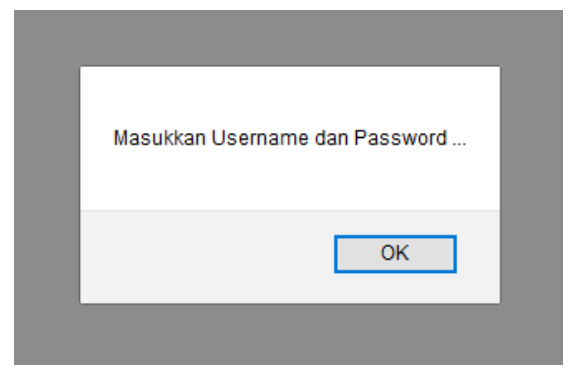

Gambar 12 Pesan error username dan password kosong

3. Pengujian login jika username dan password salah akan muncul pesan error seperti gambar 13

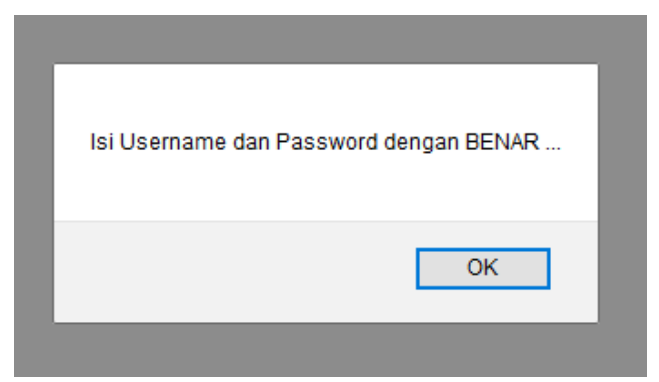

Gambar 13 Pesan error username dan password salah

4. Pengujian login jika username dan password benar akan masuk ke halaman admin seperti gambar 14

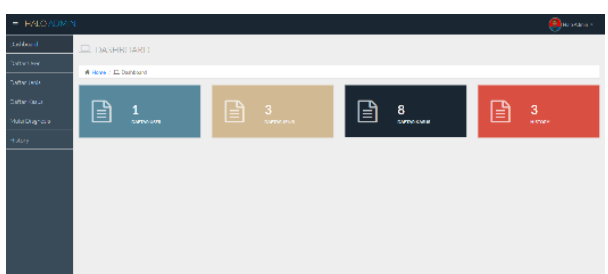

Gambar 14 Halaman admin

5. Pengujian tambah data di dapat hasil jika form tidak diisi akan muncul himbauan untuk melengkapi seperti gambar 15

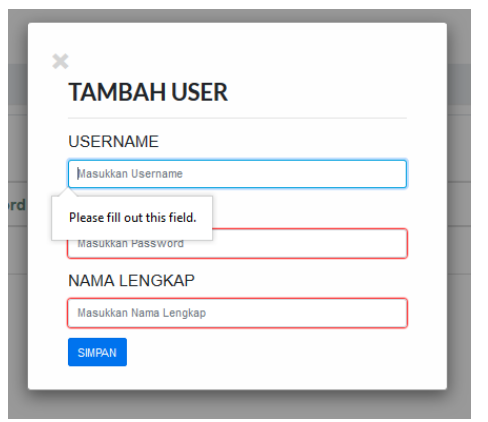

Gambar 15 Pesan error tambah data

6. Pengujian tambah data jika diisi dengan lengkap akan berhasil di input ke database seperti gambar 16

DAFTAR USER

* Home Daftar User

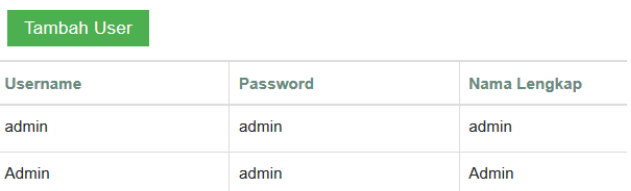

Gambar 16 tambah data berhasil di inputkan

7. Pengujian hapus data akan muncul pesan seperti gambar 18

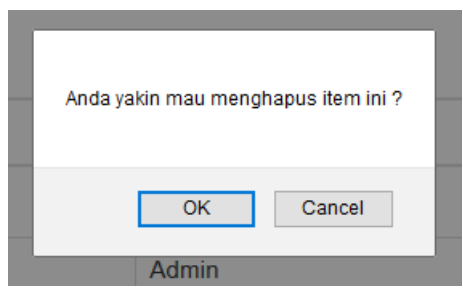

Gambar 18 Pesan hapus data

8. Pengujian hapus data berhasil dilakukan seperti gambar 19 


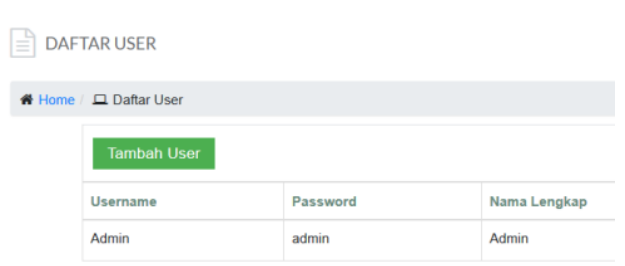

Gambar 19 Data berhasil dihapus

\section{KESIMPULAN DAN SARAN}

\subsection{Kesimpulan}

Berdasarkan pembahasan yang telah dilakukan maka didapat beberapa kesimpulan sebagai berikut:

1. Perbandingan perhitungan metode case based reasoning manual dan sistem sama

2. Pengujian sistem menggunakan blackbox

3. Proses diagnosis antara kasus lama dan baru hasil akhir sesuai dengan diagnosis.

4. Setelah melakukan diagnosis data kasus baru akan tersimpan

\subsection{Saran}

Adapun saran yang dapat diberikan setelah pengujian adalah sebagai berikut:

1. Penyempurnaan tampilan website agar lebih responsive

2. Memperbaiki tampilan website agar lebih user friendly

\section{DAFTAR PUSTAKA}

[1] Adriantantri, E., Irawan, J.D. and Prasetyo, S., 2012. SISTEM INFORMASI AKADEMIK
BERBASIS SMS DI SMPK COR JESU. Industri Inovatif: Jurnal Teknik Industri, 2(2), pp.20-24..

[2] Akmal, W. (2014). SISTEM PAKAR UNTUK MENDIAGNOSA PENYAKIT LAMBUNG. Jurnal Sarjana Teknik Informatika, 790.

[3] Binarso, d. (2012). Pembangunan Sistem Informasi Alumni Berbasis Web Pada Program Studi Teknik Informatika Universitas DIponegoro. JOINT, 76.

[4] Effendy, N. (2016). PENERAPAN FRAMEWORK BOOTSRAP DALAM PEMBANGUNAN. Jurnal Informatika Mulawarman, 10.

[5] Firman, d. (2016). Sistem Informasi Perpustakaan Online Berbasis Web. E-journal Teknik Elektro dan Komputer, 30.

[6] Harminingtyas. (2014). ANALISIS LAYANAN WEBSITE SEBAGAI MEDIA PROMOSI, MEDIA. Jurnal STIE Semarang, 42.

[7] Nasution, d. (2017). SISTEM PAKAR DIAGNOSA ANOREKSIA NERVOSA MENERAPKAN. KOMIK, 52.

[8] Radiant Adelia, M. A. (2014). Implementasi Cosine Similarity dan Algoritma SmithWaterman untuk mendeteksi kemiripan teks. Jurnal Informatika, 35.

[9] Utomo, D. (2016). SISTEM PAKAR MENDETEKSI KERUSAKAN TONER DENGAN. JURIKOM, 430.

[10] Wahyudi, H. (2017). Case-Based Reasoning untuk Diagnosis Penyakit Jantung. IJCCS, 2. 